\title{
Back to the Future Sparta, Athena, and the battle for the Arab public sphere
}

\begin{abstract}
Al Jazeera (AJ) has been a defining feature in developing news media in the Middle East and beyond. The satellite-broadcasting network has played a leading role in bringing stories and perspectives that other international media do not always cover, if at all. More importantly, it has been a champion for democracy and human rights in the Middle East, thereby provoking the ire of Arab autocratic rulers, which went to great lengths to silence the Qatar-based television news network. The latest Gulf Crisis, in which four countries (Saudi Arabia, the United Arab Emirates, Bahrain, and Egypt) blockaded Qatar in July 2017, is another attempt to silence this media institution and peg back the region to the pre-Arab Spring era. The anti-Qatar quartet issued an ultimatum of 13 demands to be fulfilled within ten days. The list included paying reparations, shutting down Al Jazeera, curbing bilateral relations with Iran, closing a Turkish military base, and submitting to monthly external compliance checks. However, the crisis could be a blessing in disguise for Qatar and the network in its campaign for greater freedom of expression in the Middle East. This article analyses the crisis from a media political economy perspective.
\end{abstract}

Keywords: Al Jazeera, Arab public space, Arab Spring, Arabia, autocracy, Bahrain, blockade, censorship, democracy, dictatorship, Egypt, fake news, Gulf Crisis, human rights, Iran, media freedom, Middle East, political economy, Qatar, satellite broadcasting, Saudi Arabia, television, United Arab Emirates

\section{TAREK CHERKAOUI}

Strategic Communications Analyst, Qatar

\section{Introduction}

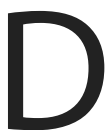

IPLOMATIC quarrels in the Arabian Peninsula have a long history, and Qatar aligned itself with stronger powers (e.g. Ottoman Empire, British Colonial Rule) in order to confront regional threats. It is conventional wisdom that states holding more power wield influence and can alter the behaviour of smaller states (Barnett \& Duvall, 2005, pp. 49-52). After the British withdrawal from east of Suez in 1971, Saudi Arabia seized the moment to bully its neighbours and claim territories from Abu Dhabi and Oman (Hellyer, 2001, 
p. 167), while also becoming the de-facto protector of Qatar. This state of affairs lasted until the early 1990s, when Saddam Hussein's Iraq invaded Kuwait and threatened to invade Saudi Arabia as well. It became quickly apparent that the Saudis were unable to defend their own borders, let alone their neighbours' too. This signalled a shift in Saudi-Qatari relations, since state survival supersedes all other considerations, and Saudi foreign policy tools that were commonly used with Gulf countries proved their limitations (Al Rasheed, 2017).

Qatar's path was therefore about to witness a major change at the hands of the Crown Prince at the time, and future Emir, Sheikh Hamad bin Khalifa Al Thani, ${ }^{1}$ who had a very different view on the future role of Qatar. He sought from the onset to resist Saudi suzerainty and pursued his nation's interest by leveraging its own capabilities and resources, unencumbered by the Saudi threat. Having the world's third-largest reserves of natural gas, the Qatari leaders chose to think outside the realm of conventional pipelines, which would have been hindered by Saudi Arabia. They focused instead on exporting liquefied natural gas (LNG) to the world through maritime routes. Thanks to the most sophisticated LNG infrastructure in the world (QNB, 2015), Qatar has become the world's largest gas exporter (EIA, 2015), and was able to fully capitalise on the basin it shares with Iran-Saudi Arabia's nemesis.

The immense revenues that followed turned Qatar into not just the world's richest nation, with an annual per-capita income of $\$ 130,000$, but also the world's largest LNG exporter (Champion, 2017). Such achievements irritated Saudi Arabia, which hoped to clip Qatar's wings and restore the status quo with the help of the United Arab Emirates (UAE) and Bahrain (Kamrava, 2009, p. 403). Relations reached their lowest point in February 1996, when an attempted coup against Qatar's leader took place. It is believed that Saudi Arabia financially supported this operation (BBC News, 2000), which severely dented Saudi-Qatari relations (Roberts, 2012). Tensions simmered back and forth between Qatar and neighbouring Gulf monarchies, and in 2014, Saudi Arabia, the UAE and Bahrain withdrew their ambassadors from the country over its support of the Arab uprisings (Kirkpatrick, 2014). Things returned to normal a year later, and nothing prepared even the most seasoned of analysts to the developments that unfolded in the closing week of May 2017. The scope of hostile actions, speed of escalation, and toxic rhetoric directed at Qatar by the quartet - the aforementioned three countries in addition to Egypt - was unparalleled.

Lacking a manifest casus belli to justify escalation, one was swiftly manufactured. On 24 May 2017, unidentified hackers exploited a cyber-bug in the website of Qatar News Agency (QNA) to disseminate fabricated news. The fake report claimed that Qatar's Emir criticized in his speech the United States, while praising Hezbollah and Hamas as resistance movements. The Qatari authorities immediately asked the United States for help, and a team from the Federal Bureau 


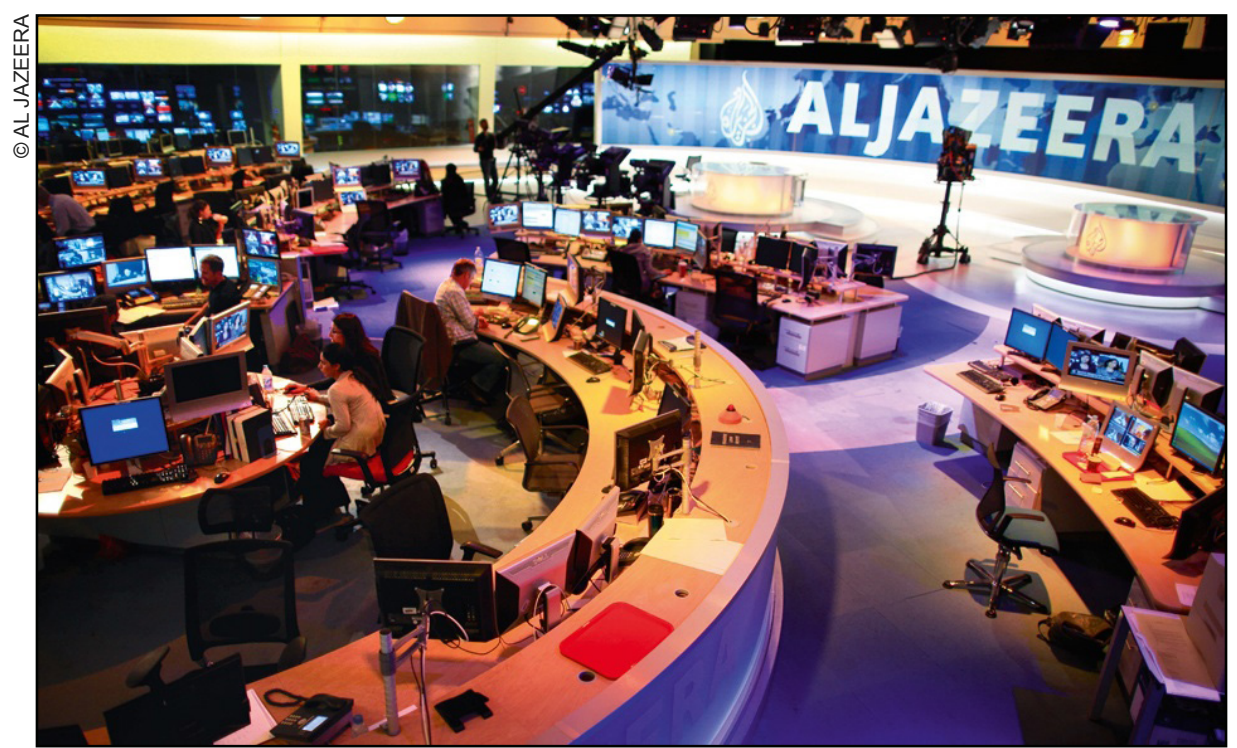

Figure 1: Al Jazeera's newsroom in Doha - target of repeated threats by the fourcountry Saudi Arabia bloc demanding close of the satellite television network.

of Investigations (FBI) led a thorough investigation. A few weeks later, Qatar's attorney general stated that communication used in the security breach originated from countries laying siege to his country. The Washington Post validated the Qatari version of events on 16 July 2017, and referred to information obtained from U.S. intelligence officials, stating that 'the United Arab Emirates orchestrated the hacking of Qatari government news and social media sites in order to post incendiary false quotes attributed to Qatar's emir, Sheikh Tamim Bin Hamad al-Thani, in late May that sparked the on-going upheaval between Qatar and its neighbours' (Nakashima \& DeYoung, 2017).

Shying away from any investigations, the anti-Qatar quartet hastily cut diplomatic ties with Doha, while also blockading Qatar's airspace and shipping channels, stopping their food supplies, and declaring Qatari nationals persona non grata, straining the region's economic and trade relations at heavy human and financial costs. The quartet not only snubbed official denials from Doha about the fake news, but they also issued an ultimatum of 13 demands to be fulfilled within ten days (McLean, El Gamal, \& Finn, 2017). The list included paying reparations, shutting down the Al Jazeera satellite-broadcasting network (AJ), curbing bilateral relations with Iran, closing a Turkish military base, and submitting to monthly external compliance checks (Middle East Eye, 2017). In the light of Doha's refusal and the shuttle diplomacy undertaken by US Secretary of State Rex Tillerson, the list was reduced to six principles (Lederer, 2017). A few weeks later, the quartet announced that the 13 demands plus the six principles were in fact still on the agenda before ceasing Qatar's blockade (Cone, 2017).

114 PACIFIC JOURNALISM REVIEW 23 (2) 2017 
In any case, the different ultimatums constituted an attempt to 'reduce Qatar to a Saudi client state, and humiliate the Emir of Qatar and the Al Thani dynasty to the point where their rule would be in question' (Lieven, 2017), and consequently they were duly rejected by Qatar. Moreover, observers believe the blockade has been counterproductive, and has in fact deepened Qatari ties with regional powers such as Turkey and Iran, as well as with two other states in the Gulf Cooperation Council: Oman and Kuwait. This has allowed for food supplies and other goods to still flow into Qatar's ports and airports (Tharoor, 2017). Consequently, the quartet no longer insisted on the 13 demands, reducing the list to six broad principles (BBC News, 2017).

However, aligning Qatar with Saudi Arabia and its allies 'militarily, politically, socially and economically' remains the end game (Lieven, 2017), and AJ's closure continues to be on the quartet's agenda. This is made especially stark when considering that its website was also blocked by the four countries' internet providers, and Saudi Arabia has banned hotels and tourist facilities from airing AJ's channels in their premises, threatening to punish contraveners with the closure of their facility and a fine of up to US\$26,000. In a statement, the Saudi Commission for Tourism and National Heritage ordered that 'all channels from the Al Jazeera Media Network must be removed' and replaced with channels compatible with 'official Saudi television ones'. Additionally, the quartet threatened lengthy jail terms and fines for their nationals if they express sympathy with Qatar on social media. The UAE said offenders would face a jail term from three to 15 years and a fine not less than 500,000 UAE dirhams (US\$136,000) (Al Jazeera, 2017).

The Saudis' tendency to impose media censorship and suppress any alternative views invites a sense of déjà $v u$. Journalist Yvonne Ridley observes:

In 1980, for example, the government in Riyadh threatened governments, politicians and TV corporations across the globe if they dared to broadcast a TV docudrama, Death of a Princess. ${ }^{2}$ The Saudis tried to intimidate Britain with economic sanctions, including the withholding of oil supplies, and recalled their ambassador from London. In the US, oil-rich companies threatened to withdraw sponsorship and advertising from TV stations if the programme was broadcast. A Middle East state attempting to gag the world? Yes, that is exactly what Saudi Arabia was doing...More than a decade later, in 1996, the BBC was forced to close down its Arabic section following pressure from Riyadh when the Saudis again sought to suppress a documentary exposing more executions in the country. Around 250 journalists lost their jobs. (Ridley, 2017)

What's more is that the quartet's representatives didn't beat about the bush and conceal their dislike for media freedoms. Saudi permanent representative to the United Nations, Abdullah al-Mouallimi said: 'If the only way to achieve 
that [i.e. the quartet's demands] is by closing down Al Jazeera, fine. If we can achieve that without closing down Al Jazeera, that's also fine. The important thing is the objective and the principle involved' (BBC, 2017). UAE representatives adopted a similar stance. When asked whether the closure of AJ was a reasonable demand, Omar Ghobash, the UAE's Ambassador to Moscow said: 'We do not claim to have press freedom. We do not promote the idea of press freedom. What we talk about is responsibility in speech' (Wintour, 2017). However, this stance drew the ire of international organisations, and Prince Zeid bin Ra'ad al-Hussein, the UN High Commissioner for Human Rights, denounced it as an 'unacceptable attack' on free speech. Faced with such an opposition, Noura al-Kaabi, the UAE Minister for the Federal National Council, said that the UAE had backed off its demands for either channel to be closed if there was a 'fundamental change and restructuring' (Philp \& Spencer, 2017).

\section{Al Jazeera: Perennial irritant for autocratic leaders}

To understand the rationale behind the attacks on Qatar in general, and AJ in particular, one must go back two decades. From the time it was launched in 1996, AJ has contributed to energise the Arab public sphere, and has been a perennial irritant for autocratic leaders and dictators in the Middle East. Before AJ's launch, government-controlled television was the defining feature of broadcasting in the region. This meant that official Arab television media was no more than a mouthpiece for government policies. Their coverage consisted mainly of barren and repetitive broadcasts, mostly intended to sing the praise of the rulers' actions (Lynch, 2005, p. 40). Even live interviews were not tolerated, as interviewees' opinions had to be checked before being aired.

The Qatari leadership minimised any government interference with the AJ network's affairs. Therefore, despite being launched as a state-financed satellite channel, the Qatari government's subtle distancing made AJ look similar to the $\mathrm{BBC}$ rather than a state-controlled Arab network. In contrast to other Arab television networks, where little to no sensitive political, social, economic, or religious subjects were ever discussed, AJ introduced a new journalistic culture to the Arab world and produced several talk shows that were fast paced, innovative, and daring. The network adopted a daring editorial line, which left no political taboos, and gave airtime to guests from across the political spectrum. After decades of state pressures and censorship, the winds of freedom blown by AJ reinvigorated the Arab public sphere in many ways (El-Nawawy \& Iskandar 2002; Miles 2005).

One weekly programme that exemplifies the change brought forward by AJ was Al Ittijah Al Mo'akis (The Opposite Direction). Launched in November 1996 (and still airing today), this programme is presented by Faisal al-Kasim, a Syrian Druze, who had worked for the BBC for many years. The presenter 
spends the first two minutes asking questions that reflect positions on a chosen topic, and then opens the floor to two guests representing opposite sides of the spectrum. The show stirred up controversies and regularly features opponents of Arab regimes, and the anchor took pride in 'de-iconising' many of the myths that have dominated the Arab world for decades (Al Kasim, 1999). It also received plenty of official complaints and censure from these governments. For example, Abdullah Al Nafisi, a Kuwaiti intellectual who was the guest of this talk show, launched a salvo of criticism against the Gulf monarchs and attacked the Saudi religious establishment for ignoring major issues such as royal corruption.

As a result, Saudi authorities added more restrictions against AJ, and coerced the only Saudi journalist working for AJ to resign from the network (El-Nawawy \& Iskandar 2002, pp. 117, 119). Also, on 27 January 1999, the programme hosted a debate about the then-raging Algerian civil war. The oppositional viewpoint clearly gained the upper hand in the debate, at which point the Algerian authorities cut the electricity supply to the capital Algiers (and other cities) to prevent the programme from screening. Even Qatari government positions constituted no red line for the daring Syrian anchor, whose programme discussed Qatar's overtures to Israel and hosted an episode titled 'Why is Qatar crawling toward Israel?' The local guest, who was a professor of political science at Qatar University, heavily and openly criticised his government's policies (Al-Kasim, 1999).

In an article he wrote for the Harvard International Journal of Press/Politics, Al-Kasim related his experience:

Al Jazeera's editorial policy is so lax that I am hardly ever given orders regarding programme content. The station has an even wider scope of freedom than the BBC Arabic radio, where I worked for 10 years. I tackle issues that I never even dreamed of covering during my service at the BBC. (Al-Kasim, 1999)

With such editorial independence, AJ exposed the misdeeds of local regimes and served as a platform for opposition groups by airing controversial debates, and exposing corruption and widespread human rights abuses. The winds of freedom blown by AJ meant also that repressive regimes no longer had the monopoly over information. By transcending borders, AJ's broadcasts were able to bypass the restrictive state media, connect with communities, challenge the official discourse, and expose the regimes' lack of legitimacy.

Arguably, AJ seems to echo the deliberative-discursive model of a Habermasian public sphere. Jürgen Habermas ${ }^{3}$ played a big role in placing the concept of public sphere at the centre of the debate on democratisation and participatory politics. It was in his seminal work, The Structural Transformation of the Public Sphere (1962), that Habermas offered the fullest articulation of the concept of the public sphere and traced its historical development economically, socially, 
politically, and institutionally. According to him, one of the most important dynamics took place when the members of the bourgeois society engaged in rational discussion through the public use of their critical judgment, which liberated them from the shackles of political and religious authorities and their imposed interpretations, leading to an early formation of public opinion. There are many parallels between this model and the democratic process in the Arab World, which needs open spaces of rational discussion. Democracy is not just a voting-centric arena, in which fixed preferences and interests compete via mechanisms of aggregation. Rather, democratisation starts when everyone has a say. Voices rather than votes are the vehicle of empowerment.

\section{Satellite television: A new Arab broadcast culture of pluralism and fairness}

Furthermore, broadcast media also bridges the gaps between different social groups and public cultures. Mass media, especially satellite television, has removed existing barriers and changed the ways these social groups and subgroupings interact with one another. Media can be a powerful vehicle in establishing a strong democratic culture by emphasizing democratic values such as tolerance, pluralism, diversity, and fairness. In this context, AJ has contributed to the making of a new political culture based on the aforementioned values, which echo the argument of several theorists, who have stressed the importance of democratic culture in bringing about democratic change. For example, academics Gabriel Almond and Sidney Verba argued in The Civic Culture: Political Attitudes and Democracy in Five Nations (1963) that a democratic form of participatory political system requires a particular political culture consistent with it. It remains debatable, though, whether democratic culture precedes the democratic process and paves the way for change, or is a result of it.

Such aspects and many more were instigated by AJ. More importantly, they obliged autocratic Arab rulers to become much more attentive to public opinion. The ruling elites viewed with deep scepticism this media institution, in which anchors and guests routinely deliberate democracy, good governance, and human rights. For them, AJ not only plays a big role in the development of free flowing information and freedom of expression, but also acts as an agency of representation that allow diverse social groups and classes to express their views that could, if left unchecked, start influencing decision making processes within their realms towards democracy.

\section{Arab Spring: A narrative seeking an end to nepotism and corruption}

By being a long champion for freedom of speech in the Arab World, and by providing airtime to dissenters, opposition groups, and controversial figures, AJ became the household name in the 1990s and 2000s in terms of advancing the democratic agenda, exposing the misdeeds, human rights abuses, and corruption of Middle- 
Eastern regimes. This stance has slowly but surely invigorated the Arab public sphere, which became much more conscious of the need for change. Therefore, when a series of uprisings and mass protests hit North Africa and the Middle East from January 2011 onwards - also known as Arab Spring - these demonstrations called for an end to nepotism and corruption, improvement of economic conditions, establishment of democratic representation, and protection of human rights.

After many years of covering events amid heavy censorship, the Qatar-based network proved very skilful in countering attempts by the different regimes to restrain the movement of its journalists. AJ, through both its Arabic and English networks (AJA and AJE), was well positioned to cover these events. With AJA already enjoying strong pan-Arabic viewership, AJE targets different Englishspeaking markets. Both networks covered events in Tunisia, when a young vegetable cart owner called Mohamed Bouazizzi immolated himself after being humiliated by police, igniting several protests across the country. AJ was one of the first outlets to broadcast pictures of his self-immolation, even though its bureau had been closed for years by the Tunisian regime.

Using mobile phone footage and social media, AJ outmanoeuvred both the Tunisian regime and competing networks by grasping very early the meaning and magnitude of the protests. They eventually brought about the demise of the Tunisian dictator; an outcome many in the region considered impossible. The 24/7 coverage provided by AJ during the Arab Spring events, combined with viral social media, online blogging, and mobile telephony, vividly publicised the uprisings. This boosted the spirits of activists and encouraged more resistance and mass defiance. Jordanian Maisara Malass, an opposition activist, described AJ as a 'media brigade' whose coverage had helped 'to spread the revolution from one city to the other' (Zayed, 2011).

AJ's Arab Spring coverage was sharp and relentless, even if at times it was deemed more sympathetic toward some particular forces, such as the Muslim Brotherhood (The Economist, 2013). Nevertheless, AJ's reporting in Egypt attracted world attention to the demonstrations and gave events a human dimension, thereby creating a bond between viewers in their living rooms and the protesters in Tahrir Square. When demonstrators ultimately forced former Egyptian President Hosni Mubarak to quit power, many people around the world embraced the narrative conveyed by AJ, whose journalistic efforts were rewarded with the Columbia Journalism Award (2011) bestowed by Columbia University's Graduate School of Journalism (Reuters, 2011).

On the other hand, the initial success encountered in some Arab Spring countries triggered heavy-handed reactions from the Gulf autocratic regimes, such as Saudi Arabia and the UAE, which felt threatened by the democratic advance in some countries (e.g. Tunisia, Egypt). Many observers might not have paid attention, but the media has often reported the rise of the UAE as the 'little 
Sparta' of the region (Chandrasekaran, 2014; Law, 2017; The Economist, 2017); a nickname that was incidentally coined by retired US General James Mattis, now Donald Trump's Secretary of Defence. Such viewpoint was echoed recently, when The Washington Post commented that 'the UAE's rise as a top-tier US military ally had set it apart from other Arab nations, enhancing its outsize ambitions and regional clout' (Fahim \& Ryan, 2017). Under the watch of Muhammad bin Zayed, the Crown Prince of the UAE, the country 'has gone from being a haven mindful of its own business into the Arab world's most interventionist regime. Flush with petrodollars, he has turned the tiny country, whose seven component emirates have a combined population of almost 10 million (only about 1 million of whom are citizens), into the world's third-largest importer of arms. He has recruited hundreds of mercenaries' (The Economist, 2017).

\section{The rise of Little Sparta}

The rise of little Sparta coincided with the Arab Spring. 'There is a dark side' to the UAE, explains veteran journalist Bill Law who reported extensively from the Middle East, 'as there was in the ferociously militaristic and authoritarian original. It is one that clashes with the brilliantly promoted image of a tolerant, tourist and business friendly oasis that the Emirates, and principally Dubai and Abu Dhabi, have so successfully projected. The UAE has relentlessly crushed human rights in its bid to silence dissent and stamp out what it sees as the pernicious influence of the Muslim Brotherhood. To that end, dozens of people have been sentenced to long terms in jail on evidence widely seen as flawed, much of it secured through coercion and torture' (Law, 2017).

It was no coincidence that the UAE (alongside the Saudis) interfered with and deteriorated the situation in the Arab countries where the Arab Spring made some noticeable progress. They incited and materially supported their proxies to use putsches, counter-revolutionary movements, false-flag terrorist groups, and extended repressive means. Such methods turned peaceful demonstrations into civil and sectarian wars, as in Libya, Syria, and Yemen. It also induced many people around the world to the fallacy of lamenting the Middle East's inability to establish modern statehood, omitting to focus on the strong nexus between the autocratic elites in the region and their foreign sponsors, which remain firmly opposed to any genuine progress for democracy in the Middle East (Davidson, 2016).

Yet, despite spending dozens of billions of dollars to restore the pre-2011 order, the Emiratis, Saudis and their proxies are still struggling to achieve dominance on the ground. Most importantly, their message has not won hearts and minds mainly because of AJ, which deconstructs the counter-revolutionary narrative at every turn. And while the UAE and Saudi Arabia have dozens of satellite television channels, such as Al-Arabiya and Sky Arabic, and tried very hard to challenge $\mathrm{AJ}$, their efforts seem to have failed, as many still consider AJ as 'the trusted eye and ears of the Arab and Muslim worlds' (Mahruqi, 2017). 


\section{Palace coup within Saudi Arabia}

Last but not least, another layer of complexity has been added to the already convoluted situation. The new Trump administration seems to have tacitly acquiesced to a palace coup within Saudi Arabia, and helped the Deputy Crown Prince, Mohamed Bin Salman (MBS), jump the succession line, and establish himself as the upcoming king (Hearst, 2017). Meanwhile, MBS has tied himself with the UAE, which is bent on pursuing its own regional influence. Amid this real-life Game of Thrones, the Trump administration has also encouraged Arab allies to form a military alliance with Israel against common foes (e.g. Hamas). As a result, governments that call for a solution to the Gaza conflict through international law (e.g. Qatar) found themselves ostracised by this new coalition. Therefore, the quartet's blockade of Qatar aims by the same token to pre-empt AJ's role in producing critical reporting in any expected war against the Palestinians.

In fact, the Israelis got a preview of such coverage's impact in July 2017, during the wave of protests by Palestinians against heightened Israeli security measures near the ancient compound, known to Muslims as al-Haram al-Sharif, which houses the al-Aqsa Mosque, Islam's third-holiest site. The ensuing closure of the al-Aqsa mosque prevented thousands from praying and resulted in a standoff. AJ's coverage of these events shed an unpleasant light on the practices of Israel to the extent that millions of viewers around the world became aware of the situation, and expressed their solidarity with the Palestinians. In the face of such opposition, Israeli Prime Minister Binyamin Netanyahu backed down from his earlier decisions. These developments are reminiscent of the 2000 Al-Aqsa Intifada, which significantly boosted AJ's international profile. At that time, as dozens of Palestinians were killed by the Israeli army and thousands were injured, Western media resorted to self-censorship, while AJA aired graphic footage of death and demolition. Netanyahu later wrote on his Facebook page:

I have spoken several times to law-enforcement authorities demanding the closure of Al Jazeera's offices in Jerusalem. If this does not happen because of legal interpretation, I will work to enact the required legislation to expel Al Jazeera from Israel. (The New Arab, 2017)

Consequently, Israeli Communications Minister Ayoub Kara convened a press conference on 6 August 2017, in which he announced a series of steps aimed at closing down Al Jazeera in Israel (Tucker, 2017). The Israeli government's reaction shows that AJ can be an ominous witness; one that the Israel-Arab coalition against terrorism, as named by President Trump, would rather do business without.

\section{Conclusion}

All things considered, at the time of writing 100 days after the start of the crisis, 
the latter continues unabated and a swift resolution seems remote. On 9 September 2017, Saudi Arabia suspended any dialogue with Qatar after a phone call between the leaders of two countries which initially suggested a breakthrough in the Gulf dispute (Reuters, 2017). It is evident, however, that the quartet has a long standing score to settle with Qatar in general, and AJ in particular. As explained earlier, the illegal blockade imposed on Qatar and threats against AJ are part of the ongoing attempts to restore the status quo in the Middle East in favour of authoritarianism and against the advancement of media freedoms and quality journalism.

Leading NGOs, such as the Committee to Protect Journalists, Human Rights Watch and Reporters Without Borders, coupled with established news publications like The New York Times (2017) and The Guardian (2017), noted such adverse development, and subsequently condemned the quartet's efforts to undermine freedom of press and international law. Beyond expressions of sympathy, Kenneth Roth, executive director of Human Rights Watch, delivered an important speech on 24 July 2017 in Doha at the Freedom of Expression conference, ${ }^{4}$ in which he concluded:

There are important things that Qatar can do to maintain the moral high ground from which it has so greatly benefited in its dispute with its neighbours. As the old adage goes, every crisis is also an opportunity. Yes, Qatar today faces a crisis, but it is also an opportunity to become a regional leader on human rights. I hope Qatar will seize that opportunity. (Roth, 2017)

Roth was exactly right, for this crisis could be a blessing in disguise. In order to counter Little Sparta, Qatar has to seize this chance, engage with its critics, and continue its political, economic, social, and legal reforms so as to become its enemy's antithesis: Athena.

\section{Notes}

1. For a short background information on the former Emir of Qatar Sheikh Hamad bin Khalifa Al Thani, the following resource is accessible: Sheikh Hamad bin Khalifa alThani, Emir. Current Leaders of Nations, Gale, 1998. Biography in Context. Retrieved on July 22, 2017, from link.galegroup.com/apps/doc/K1610000166/BIC1?u=fairfax_ main\&xid $=9 \mathrm{eb} 83 \mathrm{~b} 4 \mathrm{a}$

2. Death of a Princess was a 1980 drama-documentary that was based on the true story of a young Saudi Arabian princess and her lover who had been publicly executed for adultery.

3. Jürgen Habermas is a German sociologist and philosopher in the tradition of critical theory and pragmatism. He is best known for his theories on communicative rationality and the public sphere. Habermas argues that in a democracy-driven system, the activist public sphere is needed for debates on matters of public importance, and as well as the mechanism for that discussion to affect the decision-making process. 
4. More than 150 representatives from civil society, academia and intergovernmental human rights bodies gathered in Doha to discuss key issues in the field of free expression, including internet freedom and journalist safety in a conference organised by the Qatar National Human Rights Committee, in cooperation with the International Press Institute (IPI) and the International Federation of Journalists (IFJ). The international conference, entitled 'Freedom of Expression: Facing Up to the Threat' was held in Doha, Qatar, from 24-25 July 2017. The event was held amid a diplomatic crisis in the Middle East pitting Qatar against the quartet, which have imposed a land, air and sea blockade, and demanded that Qatar shut the influential broadcaster Al Jazeera and other media outlets.

\section{References}

Al Jazeera (2017, June 9). Saudi Arabia bans Al Jazeera channels in hotels. Retrieved from www.aljazeera.com/news/2017/06/saudi-arabia-bans-al-jazeera-channelshotels-170609141041079.html

Al-Kasim, F. (1999). Crossfire: The Arab version. The Harvard International Journal of Press/Politics, 4(3), 93.

Al-Rasheed, M. (2017). Saudi Arabia and its neighbours: A troubled relationship. Retrieved from http://studies.aljazeera.net/en/reports/2017/07/saudi-arabia-neighbourstroubled-relationship-170712101306392.html

Barnett, M., \& Duvall, R. (2005). Power in international politics. International Organization, 59(01), 39-75.

BBC News (2000). Life sentences for Qatari coup plotters. Retrieved from http://news. bbc.co.uk $/ 2 / \mathrm{hi} / \mathrm{middle}$ east $/ 660887 . \mathrm{stm}$

BBC News. (2017, July 19). Saudi-led bloc modifies demands to end Qatar crisis. Retrieved from www.bbc.com/news/world-middle-east-40654023

Champion, M. (2017, June 6). Saudi dispute with Qatar has 22-year history rooted in gas. Retrieved from www.bloomberg.com/news/articles/2017-06-06/saudi-arabia-sfeud-with-qatar-has-22-year-history-rooted-in-gas

Chandrasekaran, R. (2014, November 9). In the UAE, the United States has a quiet, potent ally nicknamed 'Little Sparta'. Retrieved from www.washingtonpost.com/world/ national-security/in-the-uae-the-united-states-has-a-quiet-potent-ally-nicknamedlittle-sparta/2014/11/08/3fc6a50c-643a-11e4-836c-83bc4f26eb67_story.html

Cone, A. (2017, July 30). Arab bloc to Qatar: Meet 13 demands before talks on boycott . Retrieved from www.upi.com/Top_News/World-News/2017/07/30/Arab-bloc-toQatar-Meet-13-demands-before-talks-on-boycott/8271501438596/

Davidson, C. (2016). Shadow wars: The secret struggle for the Middle East. London: Oneworld.

El-Nawawy, M., \& Iskandar, A. (2002). Al Jazeera: The story of the network that is rattling governments and redefining modern journalism. Cambridge: Westview Press.

Fahim, K., \& Ryan, M. (2017, August 3). The UAE's hunt for its enemies is challenging its alliance with the United States. Retrieved from www.washingtonpost.com/ world/middle_east/uaes-drive-for-regional-influence-tests-its-military-alliance-withthe-united-states/2017/08/03/448683ee-6bd2-11e7-abbc-a53480672286 story.html

Gale. (1998). Sheikh Hamad bin khalifa Al-Thani, emir. Retrieved from link.galegroup. $\mathrm{com} / \mathrm{apps} / \mathrm{doc} / \mathrm{K} 1610000166 / \mathrm{BIC} 1$ ? $\mathrm{u}=$ fairfax main\&xid=9eb83b4a

Gvalia, G., Siroky, D., Lebanidze, B., \& Iashvili, Z. (2013). Thinking outside the bloc: Explaining the foreign policies of small states. Security Studies, 22, 98-131. 
Hearst, D. (2017, April 26). Saudi palace coup: The sequel. Retrieved from www.huffingtonpost.com/entry/saudi-palace-coup-the-sequel_us_5900874ae4b00acb75f18347

Hellyer, P. (2001). The evolution of UAE foreign policy. In Al Abed, I. \& Hellyer, P. (Ed.), United Arab Emirates: A new perspective (pp. 161-178). London: Trident Press Ltd.

Kamrava, M. (2009). Royal factionalism and political liberalization in Qatar. The Middle East Journal, 63(3), 401-420.

Kirkpatrick, D. D. (3 June 2014). 3 gulf countries pull ambassadors from Qatar over its support of Islamists. The New York Times. Retrieved from www.nytimes.com/2014/03/06/ world/middleeast/3-persian-gulf-states-pull-ambassadors-from-qatar.html

Law, B. (2017, April 20). The Gulf's 'little Sparta' has big military ambitions. Retrieved from www.middleeasteye.net/columns/gulf-s-little-sparta-has-big-military-ambitions-1331398998

Lederer, E. M. (2017, July 19). Arabs urge Qatar to accept 6 principles to combat extremism. Retrieved from www.washingtonpost.com/world/middle_east/arabsurge-qatar-to-accept-6-principles-to-combat-extremism/2017/07/18/836 6 f95f4-6c 28 -11e7-abbc-a53480672286_story.html?utm_term=.3901a5aeb4c9

Lieven, A. (August, 2017). Saudi Arabia's Game. Retrieved from https://reader.exacteditions.com/issues/59299/page/15

Lynch, M. (2005). Watching Al-Jazeera. The Wilson Quarterly, 29(3), 36-45.

Maclean, W., El Gamal, R. \& Finn, T., (2017, June 23). Arab states issue ultimatum to Qatar: Close Jazeera, curb ties with Iran. Retrieved from www.reuters.com/article/ us-gulf-qatar-demands-idUSKBN19E0BB

Mahruqi, Z. (28 July 2017). Why Qatar? why now? why so much resentment? Retrieved from http:/www.eurasiareview.com/28072017-why-qatar-why-now-why-so-muchresentment-oped/

Middle East Eye (2017, June 22). Qatar crisis: Saudi-led states list 13 demands to end blockade. Retrieved from www.middleeasteye.net/news/qatar-blockade-uae-setsdemands-end-crisis-1190365222

Miles, H. (2005). Al-Jazeera: The inside story of the Arab news channel that is challenging the west. New York: Grove Press.

Nakashima, K., \& DeYoung, E. (2017, July 16). UAE orchestrated hacking of Qatari government sites, sparking regional upheaval, according to US intelligence officials. Washington Post Blogs

Philp, C., \& Spencer, R. (2017, July 13). Emirates back down over demand to shut al Jazeera. The Times, London.

Qatar National Bank. (2015, February). Qatar economic insight 2015. Retrieved from www.slideshare.net/JoannesMongardini/qnb-group-qatar-economic-insight-2015

Reuters (2011, May 4). Al Jazeera wins a top journalism prize in New York. Retrieved from www.reuters.com/article/ia-aljazeera-award-idUSN0420599920110504

Reuters (2017, September 9). Saudi Arabia suspends any dialogue with Qatar: SPA. Retrieved from www.reuters.com/article/us-gulf-qatar/saudi-arabia-suspends-anydialogue.with.qatar-spa-idUSKCNIBJ2OW

Ridley, Y. (2017, June 24). Qatar is giving Saudi and the UAE a master class in international diplomacy. Retrieved from www.middleeastmonitor.com/20170624-qatar-isgiving-saudi-and-the-uae-a-masterclass-in-international-diplomacy/

Roberts, D. B. (2012, February 28). Examining Qatari-Saudi relations. Retrieved from http://thegulfblog.com/2012/02/28/examining-qatari-saudi-relations 
Roth, K. (2017, July 26). Qatar: Finding opportunities for reform in crisis. Retrieved from www.aljazeera.com/indepth/opinion/2017/07/170726082639136.html

Tharoor, I. (2017, July 18). The blockade of Qatar is failing. Washington Post Blogs

The Economist (2013, January 12). Al Jazeera must do better. Retrieved from www. economist.com/news/middle-east-and-africa/21569429-arabs-premier-televisionnetwork-bids-american-viewers-must-do-better

The Economist (2017, April 6). The ambitious United Arab Emirates. Retrieved from www.economist.com/news/middle-east-and-africa/21720319-driven-energeticcrown-price-uae-building-bases-far-beyond-its

The Guardian (2017, June 23). The Guardian view on Al-Jazeera: Muzzling journalism. Retrieved from www.theguardian.com/commentisfree/2017/jun/23/the-guardianview-on-al-jazeera-muzzling-journalism

The New Arab (2017, July 27). Netanyahu vows to expel al Jazeera from Israel for 'inciting violence' at Al-Aqsa mosque. Retrieved from www.alaraby.co.uk/english/ news/2017/7/27/netanyahu-vows-to-expel-al-jazeera-over-al-aqsa-coverage

The New York Times (2017, June 21). Misguided attacks on Al Jazeera. Retrieved from www.nytimes.com/2017/06/21/opinion/misguided-attacks-on-al-jazeera.html

Tucker, N. (2017, August 7). Banning Al Jazeera in Israel won't be so easy. Here's why. Retrieved from www.haaretz.com/israel-news/1.805486

US Energy Information Administration. (2015). Qatar. Retrieved from www.eia.gov/ beta/international/analysis_includes/countries_long/Qatar/qatar.pdf

Wintour, P. (2017, June 28). UAE ambassador threatens further sanctions against Qatar. Retrieved from https://amp.theguardian.com/world/2017/jun/28/uae-ambassadorthreatens-further-sanctions-against-qatar

Zayani, M. (Ed.). (2005). The Al Jazeera phenomenon: Critical perspectives on new Arab media. Boulder, CO: Paradigm Publishers.

Zayed, D. (2011, January 21). Al Jazeera TV makes waves with Tunisia coverage. Retrieved from http://uk.reuters.com/article/2011/01/21/uk-tunisia-jazeera-idUKTRE70K25N20110121

Dr Tarek Cherkaoui is the author of The News Media at War. He is an authority in the field of strategic communications with a career that spans a range of industries, including the creative industries, public, not-for-profit, and higher education. Dr Cherkaoui holds a master's degree in strategic studies from the National University of Malaysia, and a PhD in media and communication studies from Auckland University of Technology, for which he obtained the 2010 Dean's Excellence Award in Postgraduate Studies. His research interests include the Arab transnational media, public diplomacy, propaganda and information control, soft power, media-military relations, political and military affairs-specifically within a Middle Eastern context. tarek_c@hotmail.com 